\title{
Male and female terminalia of four Notoschoenomyza species (Diptera, Muscidae, Coenosiinae)
}

\author{
Bianca Marques ${ }^{1} \&$ Márcia S. Couri ${ }^{1,2}$ \\ ${ }^{1}$ Departamento de Entomologia, Museu Nacional. Quinta da Boa Vista, 20940-040 Rio de Janeiro, Rio de Janeiro, Brasil. \\ E-mail: biancam@mn.ufrj.br; mcouri@attglobal.net \\ ${ }^{2}$ Research fellow of the Conselho Nacional de Desenvolvimento Científico e Tecnológico, CNPq.
}

\begin{abstract}
The terminalia of the following four species of Notoschoenomyza Malloch, 1934 are described and illustrated: Notoschoenomyza annulata (Stein, 1911); N. costata Snyder, 1957; N. immaculata (Walker, 1836); N. spinicosta (Stein, 1904).

KEY WORDS. Morphology, Notoschoenomyza annulata, Notoschoenomyza costata, Notoschoenomyza immaculata, Notoschoenomyza spinicosta.
\end{abstract}

RESUMO. As terminálias das seguintes quatro espécies de Notoschoenomyza Malloch, 1934 são descritas e ilustradas: Notoschoenomyza annulata (Stein, 1911), N. costata Snyder, 1957, N. immaculata (Walker, 1836), N. spinicosta (Stein, 1904). PALAVRAS-CHAVE. Morfologia, Notoschoenomyza annulata, Notoschoenomyza costata, Notoschoenomyza immaculata, Notoschoenomyza spinicosta.

The Neotropical genus Notoschoenomyza Malloch, 1934 is known from eigth species (Carvalho et al., 1993 and Couri \& MARQues, in press).

In the original description, MaLLOCH (1934) placed the genus close to Schoenomyza Haliday, 1833 based on external morphological characters, differing essentially in having the hind tibiae with a posterodorsal bristle near the base. In the cladistic analysis of the Coenosiinae subfamily made by CourI $\&$ Pont (2000) the genus appeared forming a clade together with Schoenomyzina Malloch, 1934; Schoenomyza and Spathipheromyia Bigot, 1884. This clade was defined by the wide frons (wider than long).

All species were recently keyed by Couri \& MARQues (in press).

Although most of them are well known in literature, they are mainly characterized based on non-terminalia characters, as few information about the male and female terminalia is found (Couri \& Pont 2000, Couri \& Carvalho 2002, Couri \& MARQues in press).

The aim of the present paper is to describe and illustrate the terminalia of both sexes, to contribute for future researches in this genus and to find further diagnostic characters.

\section{MATERIAL AND METHODS}

The material examined belongs to the Canadian National Collection, Ottawa, Canada (CNC), to Museu Nacional,
Universidade Federal do Rio de Janeiro, Rio de Janeiro, Brazil (MNRJ) and to The Natural History Museum, London, United Kingdom (BMNH), through personal notes and drawings made by M.S. Couri, during a project developed there in 1997.

The terminalia herein described are the ones of the following species: male and female: N. annulata (Stein, 1911), N. costata Snyder, 1957, N. spinicosta (Stein, 1904), only male: $N$. immaculata (Walker, 1836).

\section{Notoschoenomyza annulata (Stein, 1911) Figs $1-8$}

Male terminalia. Sternite 5 quadrangular with a strong posterior concavity (Fig. 1); ventral surface with a sclerotizated plate in center (Fig. 2). Cercal plate long and fine with many bristles; anterior margin with a long and deep incision and posterior margin with a shallow incision (Figs 3 and 4). Surstyli with round apex. Hypandrium tubular and long; aedeagal apodeme larger at apex (Fig. 5).

Female terminalia. Ovipositor long with microtrichia in all extension. Hipoproct large and epiproct ovoid (Fig. 6 and 7). Three spermathecae round and rugose (Fig. 8).

Comments. The sternite 5 is little similar to N. spinicosta except for the crown of spines present in N. spinicosta.

Examined material. Chile, Santiago: El Noviciado, 24.X.1954, L.E. Peña leg., 1 male (CNC); Pudahuel, II.1954, L.E. Peña leg., 1 female (MNRJ). 


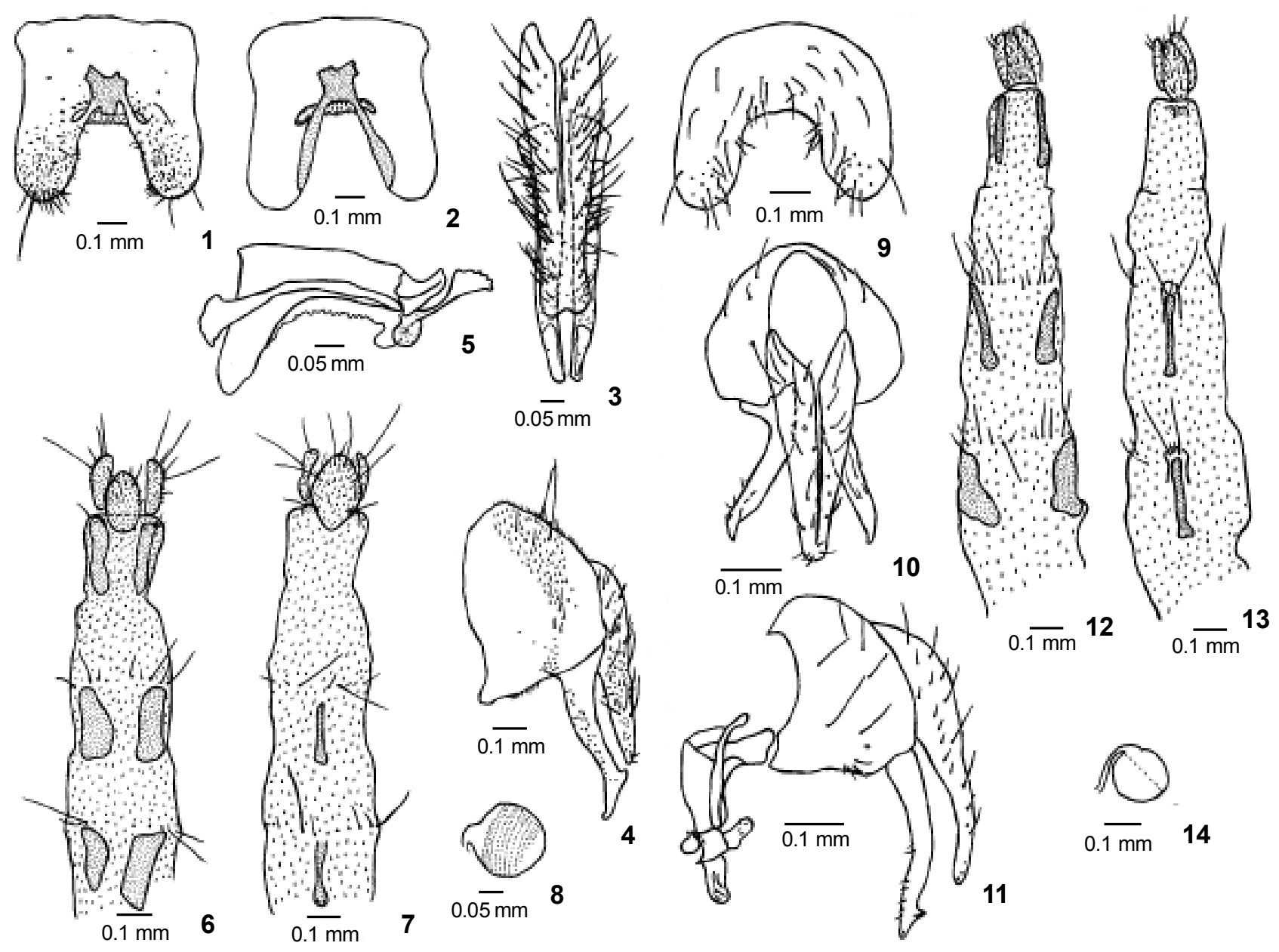

dorsal view; (4) cercal plate and surstyli, lateral view; (5) phallic complex, lateral view; (6) ovipositor, dorsal view; (7) ovipositor, ventral view; (8) spermatheca; (9-14) Notoschoenomyza costata: (9) sternite 5, dorsal view; (10) cercal plate and surstyli, dorsal view; (11) cercal plate, surstyli and phallic complex, lateral view; (12) ovipositor, dorsal view; (13) ovipositor, ventral view; (14) spermatheca.

\section{Notoschoenomyza costata Snyder, 1957}

Figs 9-14

Male terminalia. Sternite 5 with posterior concavity more or less round (Fig. 9). Cercal plate long and fine; anterior margin with a long and deep incision (deeper than in N. annulata) (Figs 10 and 11). Surstyli with narrow apex. Hypandrium tubular and long; aedeagal apodeme with more or less the same diameter in all extension (Fig. 11).

Female terminalia. Ovipositor long with microtrichia in all extension. Hipoproct and epiproct fines (Figs 12 and 13). Three spermathecae round (Fig. 14).

Examined material. Holotype male and 1 female, ArgenTINA, Tucuman: Tafi del Valle, 6.X.XII.1947, Golbach leg. (BMNH) - S.M. Tucuman.

\section{Notoschoenomyza immaculata (Walker, 1836) Figs 15-16}

Male terminalia. Sternite 5 with posterior concavity more or less round; protruded in center with a sharp process (Fig. 15). Cercal plate and surstyli long (Fig. 16). Hypandrium tubular and long; aedeagal apodeme larger at apex; epiphallus absent (Fig. 16).

Examined material. CHILE: Straits of Magellan, Port Famine, 1 male (BMNH).

\section{Notoschoenomyza spinicosta (Stein, 1904)}

\section{Figs 17-24}

Male terminalia. Sternite 5 with strong posterior concavity; center protuded with a sharp process (Fig. 17). Ventral 




15
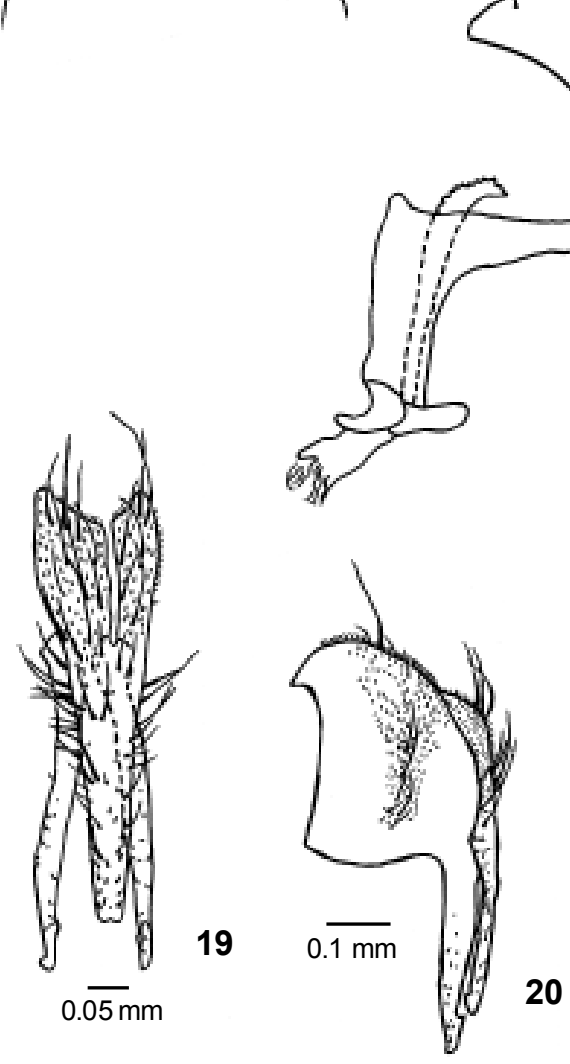



17

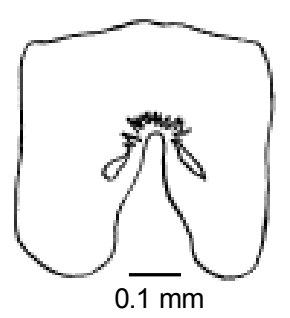

18

16


$\because \because \because$
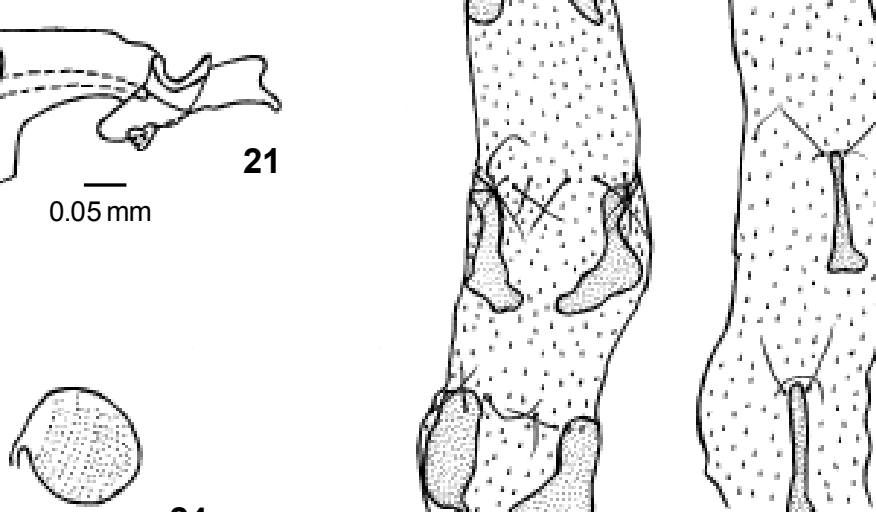

$0.0 \overline{5 m m}$

24
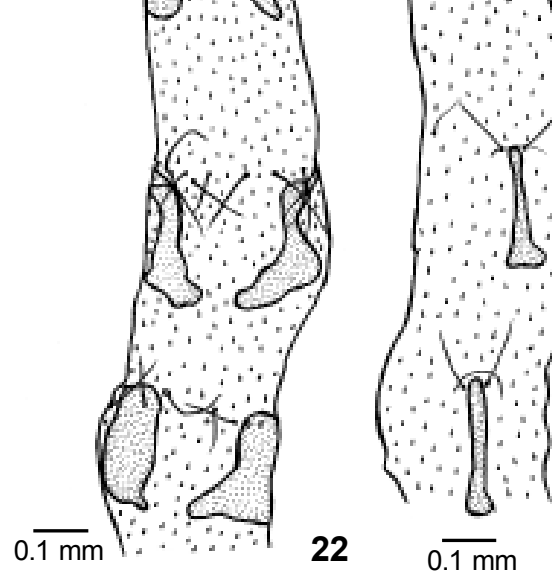

23

Figures 15-24. (15-16) Notoschoenomyza immaculata: (15) sternite 5, dorsal view; (16) cercal plate, surstyli and phallic complex, lateral view; (17-24) Notoschoenomyza spinicosta: (17) sternite 5, dorsal view; (18) sternite 5, ventral view; (19) cercal plate and surstyli, dorsal view; (20) cercal plate and surstyli, lateral view; (21) phallic complex, lateral view; (22) ovipositor, dorsal view; (23) ovipositor, ventral view; (24) spermatheca.

surface with a crown of spines in center (Fig. 18). Cercal plate long and fine with many bristles; anterior margin with a deep incision (but not deeper than in N. annulata, N. costata and N. immaculata) and posterior margin with a shallow incision (Fig. 19). Surstyli round at apex (Fig. 20). Hypandrium tubular and long; aedeagal apodeme larger at apex (Fig. 21).

Female terminalia. Ovipositor long with microtrichia in all extension. Hipoproct and epiporct large (Figs 22 and 23). Three spermathecae round, with rugose surface (Fig. 24).

Comments. The sternite 5 is very peculiar because of the presence and position of a crown of spines.
Examined material. Chile, Santiago: El Noviciado, 24.X.1954, L. E. Peña leg., 1 male (CNC); Pudahuel, II.1954, L.E. Peña leg., 1 female (MNRJ).

Discussion. Except for short comments of MALLOCH (1934) on the colour of fifth sternite and shape of the hypopygium and of Couri \& PONT (2000) on the sternite 6 and apex of the abdomen of $N$. costata, no other reference is found in literature on the terminalia of Notoschoenomyza.

The tubular shape of the hypandrium is typically found among the majority of the Coenosiini genera (Couri \& PONT 2000).

Revista Brasileira de Zoologia 21 (2): 189-192, junho 2004 
The shape of the sternite 5 , the presence of spines on its ventral surface, the length of the cercal plate and surstyli, showed to be important in the characterization of the species, based on the descriptions found in this paper, while the ovipositor is more or less homogenous within the genus.

The sternite 5 shows a variation in shape among the species, being more simple in $N$. costata and N. annulata and protruded in center with a sharp process in N. immaculata and $N$. spinicosta.

The cercal plate is long and fine in all species, but their elongation can vary, which is also a good character for the characterization of the species.

\section{ACKNOWLEGMENTS}

The authors are very grateful to Drs J.M. Cumming and J.E. O'Hara (CNC, Ottawa, Canada) for the loan of the material. M.S. Couri is gratified to $\mathrm{CNPq}$ for her research grant (process number 300386/80-0) and to FAPERJ (process E-26/ $170.627 / 2001)$ for the finnancial support to the project. B. Marques is also gratified to this agency for her grant (process
E-26/151.391/1999).

\section{REFERENCES}

Carvalho, C.J.B. De; M.S. Couri; A.C. Pont; D. Pamplona \& S.M. Lopes. 1993. Part II. Muscidae. In: C.J.B. de Carvalho (Ed.). A catalogue of the Fanniidae and Muscidae (Diptera) of the Neotropical Region. São Paulo, Sociedade Brasileira de Entomologia, 201p.

Couri, M.S. \& C.J.B. Carvalho. 2002. Part II. Apical groups, p. 133-262. In: C.J.B. de Carvalho. (Ed.). Muscidae (Diptera) of the Neotropical Region: Taxonomy. Curitiba, Editora Universidade Federal do Paraná, 287p.

Couri, M.S. \& B. Marques (in press). A new Notoschoenomyza Malloch and a key to the species (Diptera, Muscidae, Coenosiinae). Brazilian Journal of Biology.

Couri, M.S. \& A.C. Pont. 2000. A cladistic analysis of the tribe Coenosiini (Diptera, Muscidae, Coenosiinae). Systematic Entomology 25: 373-392.

Malloch, J.R. 1934. Muscidae. In: Diptera of Patagonia and South Chile, London, 7 (2): 171-346.

Received in 19.VIII.2003; accepted in 28.IV.2004.

Revista Brasileira de Zoologia 21 (2): 189-192, junho 2004 